\title{
STRUCTURE OF THE CUNICULUS NECTARY IN Brassavola flagellaris BARB. RODR. (LAELIINAE BENTH.,ORCHIDACEAE)
}

\author{
Małgorzata Stpiczyńska ${ }^{1,2}$, Kevin L. Davies ${ }^{3}$, Magdalena Kamińska1 $^{1}$ \\ ${ }^{1}$ Department of Botany, University of Life Sciences, Akademicka 15, 20-950 Lublin, ${ }^{2}$ University of Warsaw, Botanic Garden, \\ Al. Ujazdowskie 4, 00-748 Warsaw, Poland \\ ${ }^{3}$ School of Earth and Ocean Sciences, Cardiff University, Main Building, Park Place, Cardiff CF10 3AT, UK. \\ e-mail: m.stpiczynska@up.lublin.pl
}

Rerceived: 2.03.2010

\section{Abstract}

To date, the structure of the cuniculus nectary has not been studied in detail. Furthermore, the secretory mechanism of such nectaries has not been investigated. The present paper describes, for the first time, the structural organization and ultrastructure of the cuniculus nectary in the moth-pollinated orchid Brassavola flagellaris Barb. Rodr. This tubular structure is situated between the perianth tube and ovary and, in its possession of thick, cellulose cell walls, resembles the nectary of ornithophilous taxa. The presence of large secretory vesicles that fuse with the plasmalemma indicate that granulocrine nectar secretion occurs in this species. The lumen of the cuniculus is lined with unicellular hairs. However, the cuticle overlying the whole epidermal surface lining the lumen (both glabrous and pubescent regions) was coated with nectar residues and became distended and cracked, indicating that this entire tissue is probably involved in nectar secretion.

Key words: Brassavola flagellaris, Laeliinae, Orchidaceae, cuniculus nectary, secretion, anatomy, ultrastructure

\section{INTRODUCTION}

Ever since the publication of Darwin's seminal work on orchid pollination and fertilization (D a r w in, 1862), interest in the pollination strategies of Orchidaceae and modification of floral morphology in response to pollinator pressure has continued unabated to the present day (van der Pijl and Dodson, 1969; van der Cingel, 2001, and references therein). Despite this, the floral anatomy and ultrastructure of orchids, and in particular that of the nectary, has been largely overlooked. Recently, however, there has been a renewed interest in the subject (D a vi e s and Stpiczyńska, 2008; B ell et al. 2009; Matthews et al. 2009). Most of the latest literature concentrates on melittophilous, or occasionally, ornithophilous species, as well as the vestigial nectaries and spurs of nectarless orchids. However, with few exceptions, sphingophilous taxa have seldom been investigated. Consequently, the floral nectaries of most of the species studied to date are either associated with the labellar callus (D avies et al. 2005), the column (S t p i c z y ń s k a et al. 2004; 2005), or arise as a tubular, nectar spur formed by fusion of the bases of the labellum, column and tepals ( $\mathrm{P}$ a i s, 1987; $\mathrm{P}$ a i s and Figueiredo, 1994; S t piczyńska, 1997; 2003a; 2003b; Stpiczyńska and Matusiewi c z, 2001; S t pi c zy ńs ka et al. 2005). In many representatives of the sub-tribe Laeliinae Benth., however, this last type of nectary is less obvious and is called a cuniculus. This remarkable, tube-like structure is situated between the perianth tube and ovary and is evident only when the flower is cut longitudinally with a razor blade. In Epidendrum L., for example, the claw of the labellum is often united with the column to form a floral tube that is continuous with the cuniculus, whereas in other members of Laeliinae, the nectary is swollen and its position externally obvious. A cuniculus is said also to occur in Chloraea Lindl. (Diurideae Endl.), but here, two, parallel and apparently nectariferous tubes extend alongside the ovary, rather than between the ovary and perianth tube (D re s s le r, 1990).

In the present paper, we describe, for the first time, the anatomical and ultrastructural organization of the cuniculus of Brassavola flagellaris Barb. Rodr., a sphingophilous member of the Neotropical sub-tribe Laeliinae.

\section{MATERIAL AND METHODS}

Flowers of Brassavola flagellaris Barb. Rodr. were obtained from Swansea Botanical Complex, UK and their nectaries examined using light microscopy 
(LM), scanning electron microscopy (SEM) and transmission electron microscopy (TEM). Its seclusion within the cuniculus made it impossible to sample sufficient nectar for analysis without contaminating it with cell sap exuding from cut surfaces.

The nectary was investigated at the secretory stage, when the flowers were fully open. Pieces of pedicellate ovary, together with associated perianth tube and tubular nectary (cuniculus), measuring approx. $3 \mathrm{~mm}$ long, were fixed in $2.5 \%$ glutaraldehyde / $4 \%$ formaldehyde in phosphate buffer $(\mathrm{pH} 7.4 ; 0.1$ $\mathrm{M})$ for $2 \mathrm{~h}$ at ambient temperature and subsequently washed carefully three times in phosphate buffer. They were then post-fixed in $1 \%$ osmium tetroxide solution at $0^{\circ} \mathrm{C}$ for $1.5 \mathrm{~h}$, washed in distilled water and dehydrated using a graded ethanol series. Finally, material was infiltrated and embedded in LR White resin. Following polymerization at $60^{\circ} \mathrm{C}$, sections were cut at 60 $\mathrm{nm}$ for transmission electron-microscopy (TEM) using a Reichert Ultracut-S ultramicrotome and a glass knife, stained with uranyl acetate and lead citrate (Reynolds, 1963) and examined using a FEI Technai G2 Spirit Bio TWIN transmission electron microscope, at an accelerating voltage of $120 \mathrm{kV}$. Images were captured using a Megaview G2 Olympus Soft Imaging Solutions camera.

Semi-thin sections $(0.9-1.0 \mu \mathrm{m}$ thick $)$ were prepared for light microscopy (LM) and stained with $0.25 \%$ toluidine blue $\mathrm{O}$ in $0.25 \%$ (w/v) aqueous sodium tetraborate solution (TBO) or $1 \%(\mathrm{w} / \mathrm{v})$ aqueous methylene blue-Azure B solution. Hand-cut sections of fresh material were tested for the presence of starch and lignin with IKI solution and acidified, alcoholic phloroglucinol solution, respectively. Ruthenium red was used to test for the presence of acidic polysaccharides and mucilage, whereas alcoholic Sudan III was used to test for lipids (J e n s e n, 1962). Micrometry and photomicrography were undertaken using a Nikon Eclipse 600 microscope with Screen Measurement version 4.21 software.

Fixed nectary spurs were also cut longitudinally, in order to examine the epidermis lining the lumen. They were subsequently dehydrated in acetone, subjected to critical-point drying using liquid $\mathrm{CO}_{2}$, sputter-coated with gold and examined by means of a TESCAN/VEGA LMU scanning electron microscope (SEM), at an accelerating voltage of $30 \mathrm{kV}$.

\section{RESULTS}

Flowers of Brassavola flagellaris are mainly white with a pale yellow area towards the proximal part of the labellar mid-lobe, as well as around the throat of the floral tube and the entrance to the nectary (Figs 1-2). The nectary is of the cuniculus type (Figs 2-
3 ) and is positioned along the stylar canal, between the perianth tube and pedicellate ovary, at a distance of 48 $\mathrm{mm}$. At its widest point, the cuniculus lumen measures 381x $467 \mu \mathrm{m}$.

The nectary consists of a single layered secretory epidermis enclosing 2 layers of subepidermal cells (Figs 4-9). The epidermis bears numerous, unicellular, conical hairs of mean length $34.85 \mu \mathrm{m}$ (Figs 6-15), covered with a relatively thick, striated cuticle (Figs 12-13). Towards the apex of the hair, the cuticle is particularly thick (mean $4.2 \mu \mathrm{m}$ ). Nectar residues are present upon the surface of the epidermal cells (Figs 6-13), and blisters of distended cuticle burst releasing secreted nectar (Figs 10-12). Distension of the trichomal cuticle was not observed, but some secretory residues were visible on the hair surface (Fig. 13).

The epidermal and subepidermal cells are thick-walled, with a relatively thick middle lamella. Frequently, protoplasts of secretory cells are confined to a small cell cavity (Figs $6-9 ; 14 ; 16-17$ ). The outer tangential walls of the epidermis are particularly thick (mean $5.5 \mu \mathrm{m}$ ), whereas the remaining walls of epidermal and subepidermal cells are thinner (mean 2.34 $\mu \mathrm{m}$ ). The walls are composed of cellulose and pectins, but lack lignin, and nectary cells are interconnected via numerous primary pit fields containing plasmodesmata (Figs 6-7; 9; 18). The epidermal cells and cells of the subepidermal layers contain a small volume of dense, parietal cytoplasm, large nuclei and central vacuoles that stain intensely with TBO (Figs 4-9). Cytoplasmic organelles, such as mitochondria, dictyosomes and ER profiles dominate, but plastids are seldom encountered (Figs 17-25). However, the most noticeable feature is the presence of large, secretory vesicles, measuring 0.5 $-2 \mu \mathrm{m}$ in diameter. These may be empty, but usually contain globules of electron-dense material, and aggregate close to the plasmalemma (Figs 21-25). Such vesicles are also present in subepidermal cells (Figs $5-9 ; 13-15)$. The vesicle membrane and plasmalemma were frequently seen to fuse together (Figs 22; 24). However, despite the irregular internal surface of the cell wall (Figs 21-25), typical ingrowths of the latter were absent.

The nectary is supplied by several vascular bundles, embedded in the underlying parenchyma (Fig. 4) which contains numerous starch grains.

\section{DISCUSSION}

The genus Brassavola R. Br. is moth-pollinated. The sphingophilous, creamy white or pale green flowers produce heavy, pollinator-specific fragrance at night and R oe buck and S te in hart (1978) have shown that a strict relationship exists between light incidence and the regulation of fragrance production. 

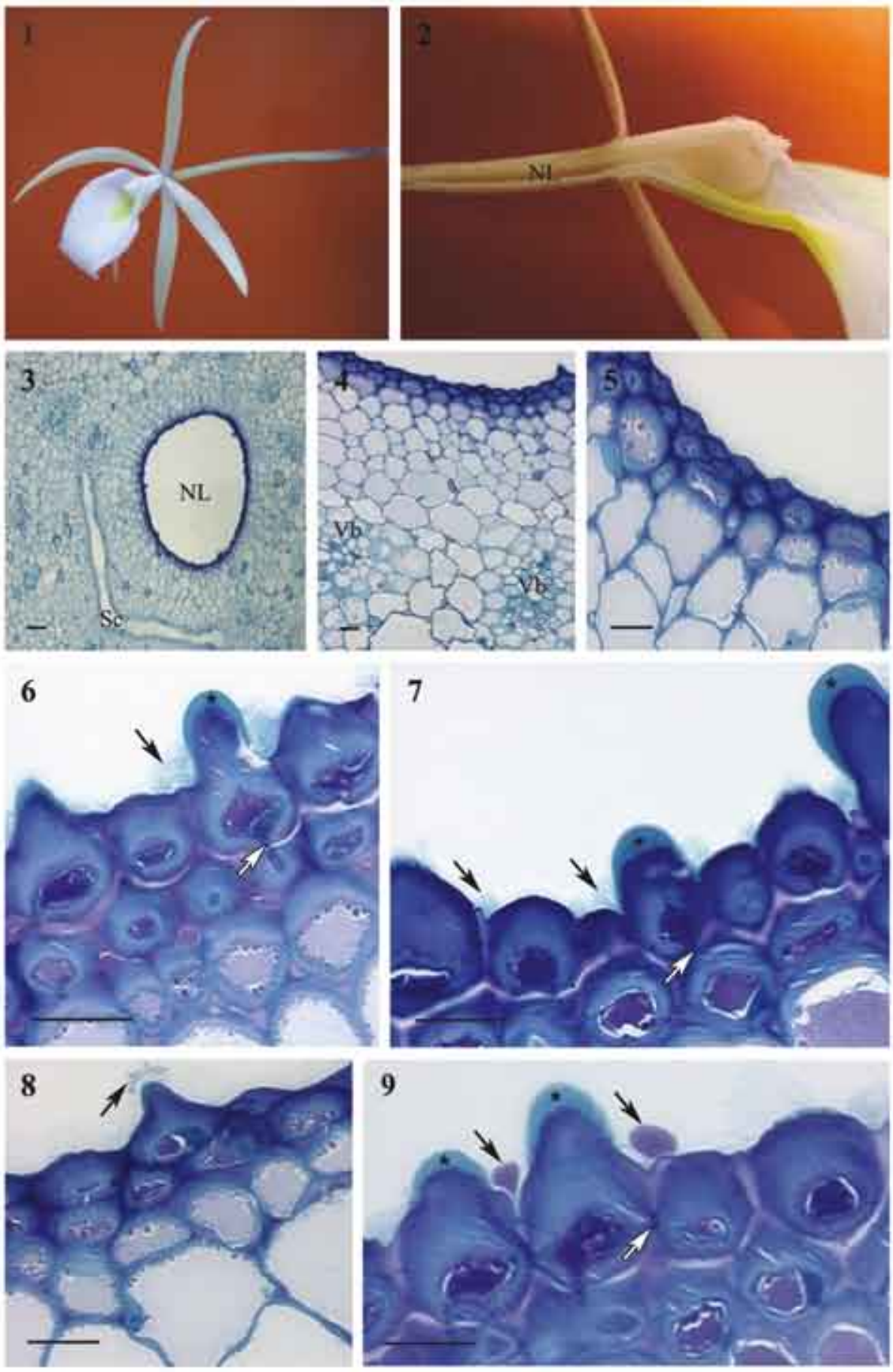

Figs 1-9. Habit of the flower and structure of cuniculus nectary in B. flagellaris (LM). Fig. 1. Habit of the flower. Fig. 2. Half flower showing position of the nectary along the ovary. Fig. 3 Transverse section of the ovary showing nectary lumen lined with darkly staining secretory cells and position of stigmatic canal. Scale bar $=100 \mu \mathrm{m}$. Fig. 4 . Darkly stained nectary secretory tissue with vascular bundles embedded in subsecretory parenchyma. Scale bar $=50 \mu \mathrm{m}$. Fig. 5. Secretory epidermis and subsecretory parenchyma. Fig. 6. Secretory tissue composed of thick-walled epidermis and two, thick-walled, subepidermal cells layers. Secretion accumulates at the base of secretory hair (arrow). Primary pit-field in walls between secretory epidermis and subepidermal cell (white arrow). Cuticle at apex of secretory hair (asterisk) is thicker than elsewhere. Fig. 7. Detail of secretory epidermis cells with intensely stained protoplasts and developing, short, secretory hairs with thick cuticle at apex (asterisks). Secretion is visible upon the surface of epidermal cells (arrows). Pit-fields (white arrow) occur in the wall between epidermis and underlying cells. Fig. 8. Epidermis and secretory hair with secretory residue at apex (arrow). Fig. 9. Thick-walled epidermal cells and secretory hairs with pronounced cuticle at apex (asterisks) and secretory residues upon the epidermal surface (arrows). Figs 5-9 scale bar $=20 \mu \mathrm{m}$. 

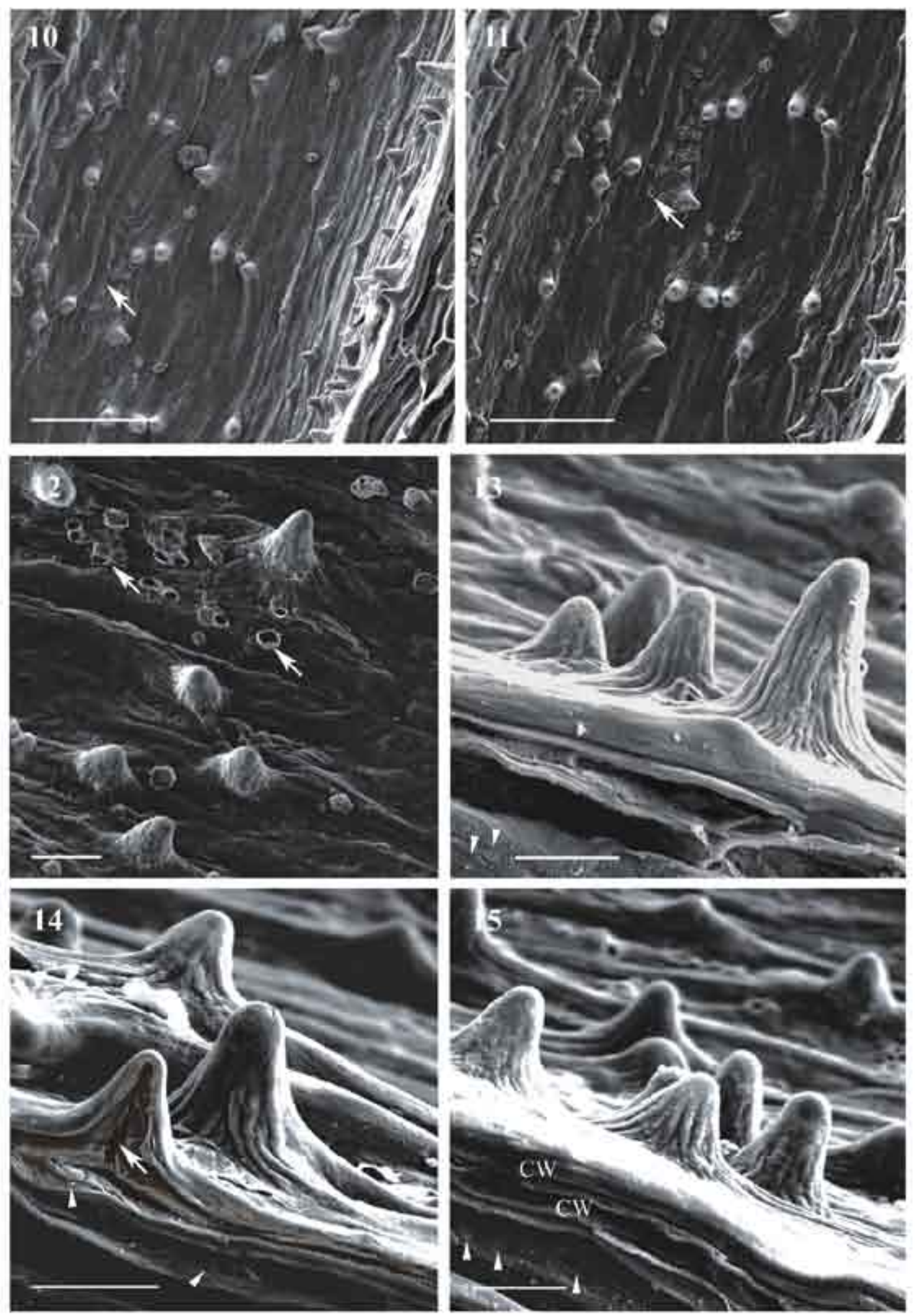

Figs 10-15. Surface of secretory epidermis (SEM). Fig. 10. Surface view of the lumen epidermis of cuniculus nectary with broken cuticular blisters (arrow). Fig. 11. Secretory hairs and distended or broken cuticle (arrow). Figs 10-11 scale bar $=100 \mu \mathrm{m}$. Fig. 12. Secretory residues and broken cuticle on the surface of epidermal cells. Fig. 13. Secretory hair with striated cuticle. Fig. 14. Secretory hairs (one cut longitudinally) with thick cell wall and narrow cell cavity containing protoplast (arrow). Secretory vesicles (arrowheads) occur in subepidermal cells. Fig. 15. Secretory epidermis with hairs. Secretory vesicles (arrowheads) are visible in sectioned epidermal and subepidermal layer. Figs 12-15 scale bar $=20 \mu \mathrm{m}$ 

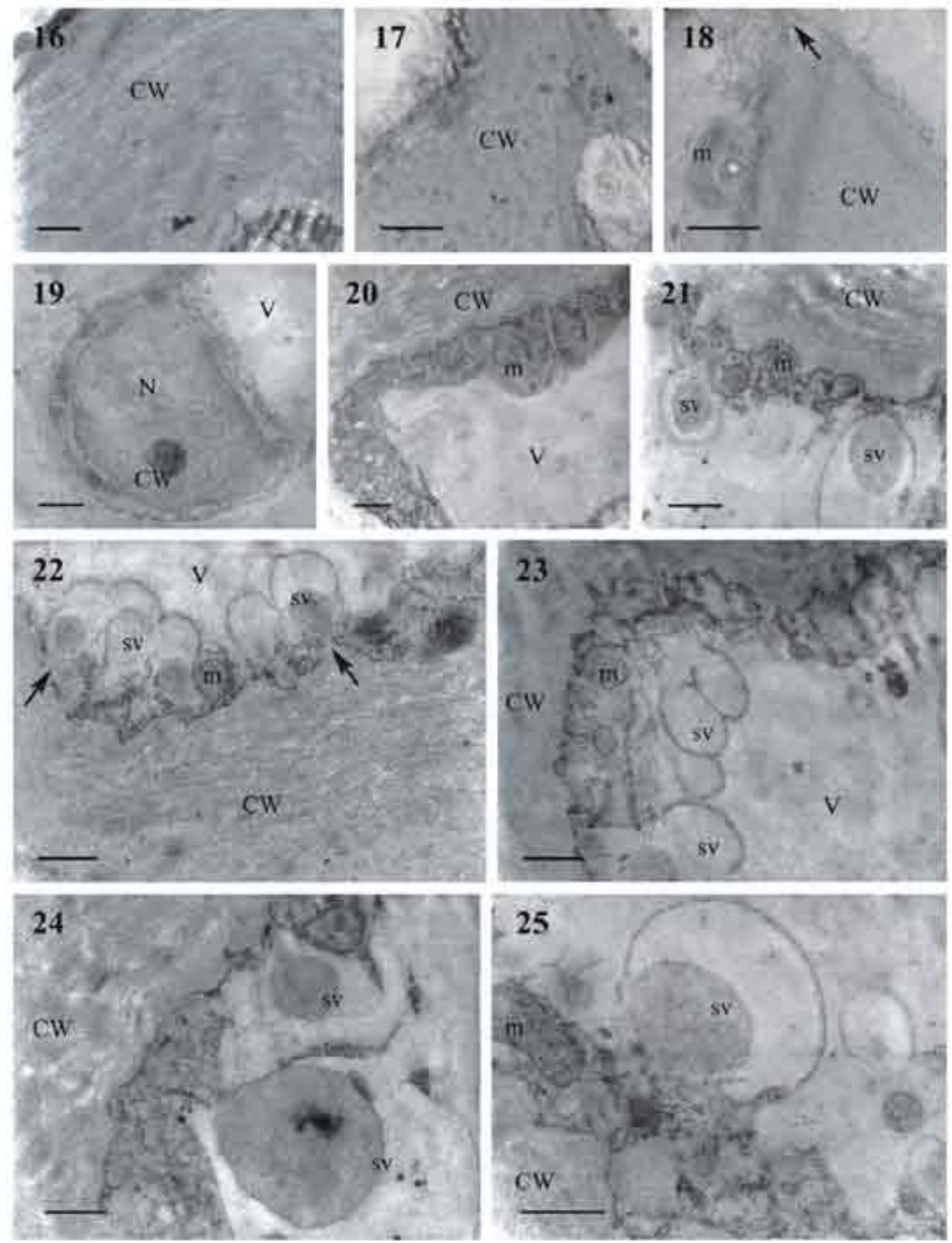

Figs 16-25. Ultrastructure of nectary secretory cells (TEM). Fig. 16. Thick lamellate outer cell wall of secretory epidermis. Scale bar $=1 \mu \mathrm{m}$. Fig. 17. Outer wall of secretory cell with secretory residues and protoplast of epidermal cell. Scale $b a r=2$ $\mu \mathrm{m}$. Fig. 18. Thick, inner tangential wall between epidermis and subepidermal cell with pit-field (arrow) and parietal cytoplasm. Scale bar $=2 \mu \mathrm{m}$. Fig. 19. Protoplast of secretory epidermis with large nucleus. Scale bar $=2 \mu \mathrm{m}$. Fig. 20 . Cell wall and protoplast of secretory epidermis with cytoplasm containing vesicles, profiles of ER and mitochondria, as well as a centrally placed vacuole. Fig. 21. Mitochondria and secretory vesicles adjacent to plasmalemma beneath outer, tangential, epidermal cell wall. Fig. 22. Fusion of membranes of secretory vesicles with plasmalemma (arrows). Note that some vesicles are empty. Fig. 23. Parietal cytoplasm of secretory epidermis with mitochondria, ER profiles, secretory vesicles and irregular outline of plasmalemma. Fig. 24. Detail of cytoplasm of secretory epidermal cell close to plasmalemma, with large secretory vesicles containing darkly stained, globules of material. Fig. 25. Detail of cytoplasm with secretory vesicles, mitochondrion and irregular outline of cell wall. Figs 20-25 scale bar $=1 \mu \mathrm{m}$.

Abbreviations: NL - nectar lumen; Sc - stigmatic canal; $\mathrm{Vb}$ - vascular bundle; $\mathrm{CW}$ - cell wall, $\mathrm{m}$ - mitochondrion; SV - secretory vesicle 
The abundant nectar is concealed in the cuniculus, and its relative inaccessibility contributes towards pollinator selection. Moreover, the flower is horizontally orientated or slightly pendulous and this, as well as the relatively reduced labellum, favours pollination by hovering insects. Although the genus is usually pollinated by moths, theft of nectar by hummingbirds has been observed in B. martiana Lindl. and B. tuberculata Hook. (B r a g a , 1977). A number of species, including $B$. nodosa, are also known to produce extra-floral nectar at the base of the sepals (W y a t t , 1982; van der C inge 1, 2001).

The reproductive biology of the genus has been the subject of several investigations. For example, $B$. nodosa (L.) Lindl.is self-compatible but not autogamous, and fruit production in this species is pollinator-limited (S c h e m s ke, 1980). Murre n and E 1 li s o n (1996) have also studied the effects of habitat, plant size and floral display on the male and female reproductive success of $B$. nodosa. Even so, the cuniculus has received little attention.

Although the flowers of B. flagellaris are clearly sphingophilous, anatomically, the cuniculus of this species resembles the nectary of certain bird-pollinated orchids, especially in that both secretory epidermal cells and subepidermal cells are collenchymatous. A cuniculus also occurs in moth-pollinated Epidendrum fulgens Brongn., a deceptive member of Laeliinae that lacks floral nectar (M o r e i r a et al. 2008), and this species too has a thick-walled epidermis with unicellular hairs lining the lumen, as well as thick-walled subepidermal cells. As with B. flagellaris (nectariferous) and E. fulgens (nectarless), nectariferous and nectarless species of Orchidinae have also been shown to have similar anatomical organization (Matthews et al. 2009; B e 11 et al. (2009).

In B. flagellaris, the secretory epidermis is pubescent. However these hairs are probably not exclusively involved in secretion, since broken cuticular blisters and nectar residues were not confined to hairs, but also occurred on glabrous regions of the epidermis. A remarkable feature of the epidermal and subepidermal cells of the cuniculus of B. flagellaris is the presence of relatively large vesicles containing darkly stained material. These vesicles are visible using LM, SEM and TEM. S k u b a t z and K u n ke l (1999) have reported similar vesicles of dictyosomal origin in the appendix of Sauromatum guttatum (Typhonium venosum (Dryand. ex Aiton) Hett. \& P. C. Boyce; Araceae), but compared with those of $B$. flagellaris, they were much smaller. In $B$. flagellaris, these secretory vesicles fuse with the plasmalemma, and this is indicative of granulocrine secretion. This mode of nectar secretion has already been proposed for a number of orchid and non-orchid species (Kronested-Robards and R ob ard s, 1991; N e p i, 2007 and references herein). However, this is the first evidence of granulocrine secretion by the cuniculus of a member of Laeliinae.

The nectary tissue of $B$. flagellaris is supplied with collateral vascular bundles. Parenchyma cells adjacent to these bundles contain numerous amyloplasts, but most nectary cells, remarkably, were almost devoid of plastids. This contrasts markedly with nectar-secreting cells of most species studied to date, where plastids either differentiate to form amyloplasts that become involved in nectar production.cells or are starchless, as in Gymnadenia conopsea (L.) R. Br. (S t p i c z y ń s k a and $\mathrm{M}$ a t u s i e w i c z , 2001), Ornithidium coccineum (Jacq.) Salisb. ex R.Br. and O. sophronitis Rchb.f. (S t p i c z y ńska et al. 2004, 2009). In Brassavola flagellaris, sugars are probably delivered to the nectary in the phloem, where they are stored temporarily in parenchyma cells as starch. This has been shown for a number of species and here, starch accumulates in the nectary, especially at the pre-secretory stage $(\mathrm{Pa}$ cin i and $\mathrm{Nepi}$, 2007).

The sub-tribe Laeliinae exhibits considerable adaptive radiation, and its members display a range of pollination syndromes that include pollination by bees, wasps, butterflies, sphingid moths, hummingbirds and flies, with many species producing rewardless flowers (va n de r Cing e l, 2001). The anatomical organization of the nectary of $B$. flagellaris is atypical of sphingophilous taxa, in that secretory cells are thickwalled. Consequently, the genus deserves further investigation and comparison with other moth-pollinated taxa assigned to this sub-tribe. Furthermore, anatomical comparisons of the cuniculus should be extended to include a range of species selected to illustrate the diversity of pollination syndromes found in Laelinae. Only then shall we be able to understand the full significance of nectary diversity in this subtribe.

\section{REFERENCES}

Almeida A. M., Figeiredo R. A. 2003. Ants visit nectaries of Epidendrum denticulatum (Orchidaceae) in a Brazilian rainforest: effects on herbivory and pollination. Brazilian J. 63: 551-558.

Bell A. K., Roberts D. L., Hawkins J. A., Rudall P. J., Box M. S., B atem an R. 2009. Comparative micromorphology of nectariferous and nectarless labellar spurs in selected clades of subtribe Orchidinae (Orchidaceae). Botanical Journal of the Linnean Society, 160: 369-387.

Braga P. 1977. Aspectos biologicos das Orchidaceae da Amazônica Central. Acta Amazonica Manaus, 7: 1-89.

D a r w in C. 1862. On the various contrivances by which British and foreign orchids are fertilized by insects and on 
the good effects of intercrossing. John Murray. London.

Davies K. L., St piczyńska M., Gregg A. 2005. Nectarsecreting floral stomata in Maxillaria anceps Ames \& C. Schweinf. (Orchidaceae). Ann. Bot. 96: 217-227.

Kronested-Robards E., Robards A. W. 1991. Exocytosis in gland cells. Endocytosis, exocytosis and vesicle traffic in plants. Wyd. C.R. Hawes, J.O.D. Coleman, D.E. Coleman (Eds) Cambridge Univ. Press: 199-232.

Matthews ML, Cozzolino S, Schiestl F. 2009. Nectary and spur structure and evolution in rewarding and deceit-pollinated Orchidinae (Orchidaceae). Conference Proceedings Charles Darwin's 200th Birthday 150 years "Origin of species" University of Bern and Natural History Museum, 12-13th February 2009.

Moreira A. S. F. P., Fuhro D., Isaias R. M. S. 2008. Anatomia floral de Epidendrum fulgens Brongn. (Orchidaceae - Epidendroideae) com ęnfase no nectário e sua funcionalidade. Rev. Biol. Trop. 5: 23-29.

Murren C. J., E11 is on A. M. 1996. Effects of habitat, plant size, and floral display on male and female reproductive success of the neotropical orchid Brassavola nodosa. Biotropica, 28: 30-41.

Ne pi M. 2007. Nectary structure and ultrastructure. [In]: Nectaries and Nectar. S. Nicolson, M. Nepi, E. Pacini (eds): 129-166. Springer, Dordrecht.

Pacin i E., Nepi M. 2007. Nectar production and presentation. [In]: Nectaries and Nectar. S. Nicolson, M. Nepi and E. Pacini (eds): 167- 214. Springer, Dordrecht.

Pansarin E. R, A maral M. C. E. 2008. Reproductive biology and pollination mechanisms of Epidendrum secundum (Orchidaceae). Floral variation: a consequence of natural hybridization? Plant Biol. 10: 211-219.

Roebuck K. I. Stein hart W. L. 1978. Pollination ecology and the nocturnal scent response in the genus Brassavola. Amer. Orchid Soc. Bull., 47: 507-511.

Rudal P. 2002. Homologies of inferior ovaries and septal nectaries in monocotyledons. Inter. J. Plant Sci. 163: 261-276.

S chem ske D. W. 1980. Evolution of floral display in the orchid Brassavola nodosa. Evolution, 34: 489-493.

S ing e r R.B., Marsaioli A.J., Flach A., Reis M.G. 2006. The ecology and chemistry of pollination in Brazilian orchids: Recent Advances. [In]: Floriculture, Ornamental and Plant Biotechnology Vol. IV Global Science Books: 569-582.

Skubatz H. Kunkel D. 1999. Further studies of the glandular tissue of the Sauromatum guttatum (Araceae) appendix. Amer. J. Bot. 86: 841-854.

Smidt E.C., Silva-Pereira V., B orba E. L. 2006. Reproductive biology of two Cattleya (Orchidaceae) species endemic to north-eastern Brazil. Plant Species Biol. 21: 85-91.

Stpiczyńska M. 1997. The structure of nectary of Platanthera bifolia L. Orchidaceae. Acta Soc. Bot. Pol. 66:5-11.
Stpiczyńska M. 2003a. Nectar resorption in the spur of Platanthera chlorantha (Custer) Rchb. - structural and microautoradiographic studies. Plant Syst. Evol. 238: 119-126.

Stpiczyńska M . 2003b. Incorporation of 3H-sucrose after the resorption of nectar from the spur of Platanthera chlorantha (Custer) Rchb. Can. J. Bot. 81: 927-932.

Stpiczyńska M., Davies K. L. 2006. Nectary structure in Symphyglossum sanguineum (Rchb.f.) Schltr. (Orchidaceae). Acta Agrobot. 59: 7-16.

Stpiczyńska M., Davies K. L., Gregg A. 2005. Comparative account of nectary structure in Hexisea imbricata (Lindl.) Rchb. f. (Orchidaceae). Ann. Bot. 95: 749-756.

St piczy ńska M., Davies K. L., Gregg A. 2004. Nectary structure and nectar secretion in Maxillaria coccinea (Jacq.) L.O. Williams ex Hodge (Orchidaceae). Ann. Bot. 93: 87-95.

Stpiczyńska M., Matusiewicz J. 2001. Anatomy and ultrastructure of the spur nectary of Gymnadenia conopsea L. (Orchidaceae). Acta Soc. Botan. Pol. 70: 267272.

Stpiczyńska M., Milanesi C., Faleri C., Cresti M. 2005. Ultrastructure of the nectary spur of Platanthera chlorantha (Custer) Rchb. (Orchidaceae) during successive stages of nectar secretion. Acta Biol. Crac. 47: 111-119.

van der Cingel N. A. 2001. An atlas of orchid pollination: America, Africa, Asia and Australia. AA. Balkema Publishers, Rotterdam.

va n der Pijl L., D od s on C. H. 1969. Orchid flowers: their pollination and evolution. University of Miami Press, Coral Gables, Florida.

Vieira M. F., Andrade M. R. S., Bittencourt N. S., Carvalho-Okano R. M. 2007. Flowering phenology, nectar structure and breeding system in Cymborkis flava (Spiranthoideae: Tropideae), a terrestrial orchid from a Neotropical forest. Australian J. Bot. 55: 635-642.

Singer R. B., C o c u c ci A.A. 1999. Pollination mechanisms in four sympatric southern Brazilian Epidendroideae orchids. Lindleyana, 14: 47-56.

Vogel S. 1979. Evolutionary shifts from reward to deception in pollen flowers. [In]: Richards A. J. (ed) The Pollination of flowers by insects. Academic Press, London: 89-96.

Vogel S. 1981. Bestäubungskonzepte der Monokotylen und ihr Ausdruck im System. Berichte der Deutschen Botanischen Gesellschaft, 94: 663-675.

Wyatt R. 1982. Inflorescence architecture: how flower number, arrangement and phenology affect pollination and fruit set. Amer.J. Bot. 69: 585- 594. 
Budowa nektarnika typu cuniculus u Brassavola flagellaris Barb. Rodr. (Laeliinae Benth., Orchidaceae)

$$
\text { Streszczenie: }
$$

W niniejszej pracy po raz pierwszy została opisana budowa anatomiczna i ultrastruktura nektarnika typu cuniculus u Brassavola flagellaris Barb. Rodr., gatunku zapylanego przez ćmy. Ten tubularny nektarnik jest usytuowany pomiędzy rurką kwiatową i zalążnią, a jego budowa anatomiczna i grube, celulozowe ściany komórkowe tkanki wydzielniczej przypominają strukturę nektarników u storczyków zapylanych przez ptaki. Obecność dużych pęcherzyków wydzielniczych w przyściennej cytoplazmie, których błony łączą się z plazmalemmą wskazuje na pęcherzykową (granulocrine) sekrecję nektaru poza protoplasty komórek wydzielniczych. Epiderma pokrywająca nektarnik tworzy jednokomórkowe włoski. Jednakże kutykula, która powleka całą powierzchnię epidermy wydzielniczej (zarówno płaskie komórki jak i te wytwarzające włoski) jest pokryta pozostałościami nektaru, a na jej powierzchni widoczne są uwypuklenia i pęknięcia, co może wskazywać na fakt, że cała powierzchnia epidermy jest zaangażowana w proces sekrecji. 